\title{
Readiness and barriers to adopt evidence-based practices for substance abuse treatment in Mexico
}

\author{
Viviana E. Horigian,' Paula S. Espinal,' Elizabeth Alonso,' Rosa E. Verdeja,' Rui Duan,' Ingrid M. Usaga,' \\ Alejandro Pérez-López, ${ }^{2}$ Rodrigo Marín-Navarrete, ${ }^{2}$ Daniel J. Feaster ${ }^{1}$
}

Original artícle

\section{ABSTRACT}

\section{Introduction}

Evidence shows a lag in adoption of evidence-based practices (EBPs) for substance abuse treatment and supports the need for studying the factors involved in this worldwide problem.

\section{Objective}

This study aimed to assess the readiness and barriers to adopt EBPs for substance abuse in a sample of outpatient treatment centers of a newly created Mexican Clinical Trials Network.

\section{Method}

An online survey was administered to directors $(n=8)$ and clinicians $(n=40)$ from seven outpatient treatment centers in Mexico. Questions were obtained from two surveys that had been implemented in the US to assess the same objectives.

\section{Results}

Respondents reported being more ready to adopt Cognitive Behavioral Therapy (CBT, 83.3\%) and Motivational Enhancement Therapy (MET, 79.1\%), compared to 12 step facilitation (58.3\%), couples therapy (56.2\%), Brief Strategic Family Therapy (BSFT, 66.6\%), and motivational incentives $(60.4 \%)$. Directors had lower mean resistance to EBPs (1 1.8 vs. 17.4; $p=0.01)$ than clinicians. The biggest barriers identified by directors to EBP adoption were not having enough clinical staff, being unable to afford well-trained staff, not enough psychiatric and medical support.

\section{Discussion and conclusion}

CBT and MET emerged as the most frequently used evidence based practices in the sites that are part of the Mexican Clinical Trials Network. Staff positive attitudes towards EBPs are critical for adoption.

Key words: Evidence-based practice, treatment services, adoption, substance abuse, dissemination research, barriers.

\section{RESUMEN}

\section{Introducción}

La literatura demuestra una demora en la adopción de las practicas basadas en la evidencia (PBEs) para el tratamiento del abuso de sustancias y apoya la necesidad de estudiar los factores involucrados en este problema mundial.

\section{Objetivo}

Este estudio evaluó la disponiblildad y las barreras de la adopción de PBE para el abuso de sustancias en una muestra de centros pertenencientes a la nueva Red Mexicana de Ensayos Clinicos.

\section{Método}

Se administró una encuesta online a directores $(n=8)$ y a clinicos $(n=$ 40) de siete centros de tratamiento ambulatorio para el tratamiento de las adicciones en México. Las preguntas se obtuvieron de dos encuestas que se administraron en los Estados Unidos con los mismos objetivos.

\section{Resultados}

Los encuestados reportaron estar más dispuestos a la adopción de la Terapia Cognitivo Conductual (CBT,83.3\%) y Terapia de Incremento Motivacional (MET, 79.1\%),comparado con la facilitación de los 12 pasos $(58.3 \%)$,terapia de pareja $(56.2 \%)$, Terapia Familiar Breve y Estratégica (BSFT, 66.6\%),e incentivos para la motivación (60.4\%). Los directores tuvieron menor promedio de Resistencia a las PBEs (11.8 vs. 17.4; $p$ $=0.01$ ) que los clinicos. Las principales barreras identificadas por los directores fueron no tener suficiente personal clínico, no poder costear personal altamente entrenado, apoyo psiquiátrico y médico insuficiente.

\section{Discusión y conclusión}

La CBT y la MET emergieron como las PBEs usadas con mayor frecuencia en centros que son parte de la Red Mexicana de Ensayos Clínicos. Las actitudes positivas del personal hacia las PBEs son críticas para la adopción.

Palabras clave: Prácticas basadas en la evidencia, servicios de tratamiento, adopción, uso de sustancias, investigación de diseminación, barreras.

Miller School of Medicine, University of Miami, Miami, FL, USA

2 Clinical Trials Unit on Addiction and Mental Health. Instituto Nacional de Psiquiatría Ramón de la Fuente Muñiz, Mexico City, Mexico.

Correspondence: Viviana E. Horigian, M.D. Miller School of Medicine, Department of Public Health Sciences, University of Miami, 1120 NW 14 th Street, CRB 1011, Miami, Florida 33136. Tel: (305) 243 - 4305. Fax: (305) 243 - 4417. E-mail: vhorigian@med.miami.edu

Recibido primera versión: 5 de enero de 2016. Segunda versión: 10 de enero de 2016. Tercera versión: 13 de enero de 2016. Cuarta versión: 2 de marzo de 2016. Aceptado: 2 de marzo de 2016 


\section{INTRODUCTION}

Literature shows a gap between research and practice in substance abuse treatment, and points towards the importance of studying the barriers to adoption of evidence-based practices (EBPs). ${ }^{1-4}$ Different perspectives among researchers, treatment organizations, and treatment providers on issues surrounding service delivery, structural and financial barriers, education and training, and policies that impede treatment options, are some of the reasons for the slow dissemination and adoption of EBPs in substance abuse treatments settings. ${ }^{3,5-8}$

Adoption and implementation of evidence-based practices (EBPs) for substance abuse in real world treatment settings is a challenge, both in the US and abroad. In the US, two large infrastructures were developed to address the research-practice gap and facilitate dissemination and adoption of EBPs for substance abuse treatment: The National Drug Abuse Treatment Clinical Trials Network (NIDA CTN), ${ }^{9}$ and the Addiction Technology Transfer Centers. ${ }^{10}$ In Mexico, a Mexican Clinical Trials Network (Red de Ensayos Clínicos-REC, in Spanish) was created, following the model of the US NIDA CTN, ${ }^{11}$ to address the shortage of rigorous clinical trials in substance abuse treatment, ${ }^{12,13}$ and facilitate the adoption of EBPs by bringing together researchers and providers to develop and test interventions for substance abuse treatment in real world settings.

The Mexican Clinical Trial Network, established in 2011, brought together the National Institute of Psychiatry, an academic institution which leads the country's research efforts and provides specialized substance abuse and mental health services to the community, and two large networks of treatment centers: The Juvenile Integrative Centers (Centros de Integración Juvenil, in Spanish) and the Centers for Substance Abuse for First Level of Care (Centros de Atención Primaria en Adicciones -CAPA- in Spanish). The US and Mexican Clinical Trials Networks aim to bridge the gap between research and practice through the establishment of collaborative relationships between researchers and practitioners. Challenges still remain and are being studied in the US. ${ }^{14-18}$ It is important to understand the challenges for adoption of EBPs in substance abuse treatment in Mexico as the network evolves.

This study assessed readiness to adopt EBPs by substance abuse community treatment providers within the recently established Mexican Clinical Trials Network, characteristics of the workforce, their current practices and frequency of use of EBPs for the diagnosis and treatment of substance abuse, their attitudes towards EBPs, and barriers regarding the implementation of EBPs for substance abuse treatment. The study also aimed to evaluate whether sites that participated in the first randomized clinical trial for the Mexican Clinical Trials Network differed from those that did not, in the practice of, and readiness to adopt EBPs, in their attitudes towards EBPs and in their interest in using EBPs.

\section{METHOD}

Directors and clinicians from seven community treatment centers for substance abuse in Mexico completed a survey developed for this study, adapted from those used by McGovern, Fox, Xie \& Drake ${ }^{3}$ and Haug, Shopshire, Tajima, Gruber \& Guydish. ${ }^{1}$ This study was approved by University of Miami International Review Board (IRB) and by the Ethics and Research Commision at National Institute of Psychiatry Ramón de la Fuente Muñiz in Mexico (Comisión de Ética del Instituto Nacional de Psiquiatría Ramón de la Fuente Muñiz).

\section{Recruitment}

Participating treatment centers were part of the Mexican National Clinical Trials Network and all are government funded. Four of them are First Level of Care Centers for Substance Abuse treatment and two of the centers are part of an institution supported by a civil association, Juvenile Integration Centers. One center is located in the National Institute of Psychiatry Ramón de la Fuente Muñiz and is a specialized center for substance abuse treatment. Three centers are located in Mexico City, two in Puebla, and three in Estado de Mexico. Three centers that participated in this study also participated in the first trial implemented in the network, a trial of Motivational Enhancement Therapy (MET) for substance use. The remaining participating sites were part of the site selection process for the first trial, but were not selected for trial participation. A total of eight directors and 40 clinicians, from seven centers, responded to the survey for this study.

The Principal Investigator from the University of Miami, in collaboration with the Director of the Mexican network, contacted each center director to present this study and request their site's participation. All sites agreed to participate and were asked to provide a day in which the online self-report surveys could be conducted. To maximize responses and address any technical issues during implementation, a team consisting of one research staff member from the University of Miami and one from the National Institute of Psychiatry Ramón de la Fuente Muñiz presented the study and facilitated the data collection in each site. The staff members that implemented the survey had not participated in the selection nor implementation of the first trial supported by the network, which helped control potential bias in the presentation of the study to participants.

\section{Director and clinician surveys}

Surveys were programmed for online administration and hard copy versions were available for use if the internet service was not available. To construct the surveys, questions from the McGovern, Fox, Xie \& Drake ${ }^{3}$ and Haug, Shopshire, Tajima, Gruber \& Guydish ${ }^{1}$ surveys were select- 
ed, compiled, adpated and translated into Spanish. Director and clinician surveys had 49 and 33 items, respectively; and included questions on demographics and professional characteristics of both programs directors and clinicians, characteristics of the centers and their populations, current practices, readiness to adopt and attitudes towards EBPs. Director surveys included additional questions on staffing characteristics at their site as well as their perceived barriers to adopt EBPs. An anonymous linkage code was used to identify each participant's responses.

To assess current practices at participating sites, a list of current recommended/best evidence-based treatments, services and tools were created. Participants were asked to indicate how frequently they implemented certain EBPs. Response options ranged from never or almost never to almost always / always on a five point Likert scale, and results were aggregated into not frequently (including 1: never or almost never, and 2: sometimes) and frequently (including 3: frequently, 4: most of the times, and 5: almost always/always).

To assess the level of readiness to adopt EBPs, participants were asked to rate their use of different EBPs on a six point scale, as follows: 1- I'm not familiar; 2- I'm not interested; 3- I've seriously considered learning about this practice but I see too many cons; 4- I'm inclined to use/adopt this practice in our program; 5 - I just started using this practice in our work; 6- I've been using and sustaining it. These response options reflect the stages of change to adopt EBPs: pre-contemplation (1-2), contemplation (3), preparation (4), action (5), and maintenance (6) (Prochaska JO, DiClemente CC, 1982). As stage four represents the stage of preparation, it was used as a cut-off point to establish level of readiness. Those that scored four or above were considered more poised to use EBPs, compared to those with a score lower than four. Attitudes towards the use of EBPs were obtained from participants' ratings on items on a five point rating scale where 1-corresponded to strongly disagree; 2-disagree; 3-not sure; 4-agree; 5-strongly agree. Results were aggregated into disagree (including 1-strongly disagree and 2-disagree), not sure (3-not sure) and agree (including 4-agree, and 5-strongly agree). Mean scores were obtained for responses on each item.

With the intention of identifying existing barriers to EBPs implementation, site directors answered a set of questions in which they had to rank their responses from 1- being most significant to 10 - being the least significant.

\section{Implementation}

Assessments were conducted over a two week period in December 2013. On the day of the site visit, the research team met with the site directors and clinicians to present the study, its anonymous and voluntary nature and the process of data collection. Participants were informed that leaders at their centers would not have access to their responses.
Each participant used a laptop to complete the self-report survey. An electronic consent form, approved by the above mentioned IRBs, preceded the survey. Prospective participants could accept or decline participation prior to opening the survey. Each survey took 15-30 min to complete. Participating centers received a copy of the DSM-5 or a copy of the American Psychiatric Publishing Textbook of Substance Abuse Treatment, 4th Ed. as an incentive for participation.

\section{Statistical analysis}

Questionnaire responses were compiled to produce descriptive statistics. Fisher's Exact Test was performed to test for statistical differences between the seven sites, on their level of frequency of use of EBPs; as well as to evaluate differences between participants and non-participants of the Mexican MET trial on their current practices, readiness to adopt evidence based practices, attitudes towards the use of EBPs and barriers for the implementation of EBPs.

\section{RESULTS}

The table 1 describes the demographic and professional characteristics of program directors and clinicians. Two thirds of directors and clinical staff were female and the average age was 42 and 39 respectively. Both directors and clinicians had long tenures at their treatment centers, and in the addiction field. Ninety four percent of directors and clinicians had some degree of higher education. Seventy five percent of the clinicians and directors indicated that direct work with patients was their primary responsibility. Only one of the clinicians reported being in personal recovery.

As seen in table 2, the theoretical framework to substance abuse treatment most frequently used by directors and clinicians were: Cognitive-behavioral (CBT) (37.5\%), Bio-psychosocial (22.9\%), and Eclectic (14.5\%). Half of respondents reported that $50 \%$ or more of their patients presented with dual diagnoses. Respectively, $62.5 \%$ and $30.7 \%$ of directors and clinicians reported having participated in the Mexican MET trial, and 75\% of directors knew what the Mexican Clinical Trials Network was, compared to less than $46.1 \%$ of clinicians.

The table 3 presents reported current clinical practices, and the degree of use of certain EBPs (diagnostic and therapeutic) by the respondents across both groups -program directors and clinicians. Ratings for these practices ranged from never or almost never to almost always/always on a 5- point rating scale. Responses were aggregated into not frequently (including answers: never or almost never and sometimes) and frequently (including answers: frequently, most of the time, and always). Fewer respondents reported using the Addiction Severity Index (29.5\%), compared to the DSM-IV/5 (81.8\%), and ICD-10 (78.2\%). The behavior- 
Table 1. Demographic and professional characteristics of program directors and clinicians

\begin{tabular}{|c|c|c|}
\hline & $\begin{array}{l}\text { Directors } \\
n=8(\%)\end{array}$ & $\begin{array}{l}\text { Clinicians } \\
n=40(\%)\end{array}$ \\
\hline a. Mean age & $\begin{array}{l}M=41.8 \\
(S D=7.7)\end{array}$ & $\begin{array}{c}M=39.1 \\
(S D=10.6)^{* * *}\end{array}$ \\
\hline \multicolumn{3}{|l|}{ b. Gender* } \\
\hline Male & $2 / 8(28.5)$ & $10 / 40(25.6)$ \\
\hline Female & $5 / 8(71.4)$ & $29 / 40(74.3)$ \\
\hline \multicolumn{3}{|l|}{$\begin{array}{l}\text { c. Years of experience in addic- } \\
\text { tion field** }\end{array}$} \\
\hline$>5$ years & 7 (87.5) & $14 / 40(42.4)$ \\
\hline$\leq 5$ years & 1 (12.5) & $19 / 40(57.5)$ \\
\hline \multicolumn{3}{|l|}{ d. Years working at current site* } \\
\hline$>5$ years & 1 (12.5) & $11 / 40(33.3)$ \\
\hline$\leq 5$ years & 7 (87.5) & $22 / 40(66.6)$ \\
\hline \multicolumn{3}{|l|}{ e. Clinical certification* } \\
\hline Yes, National degree & $8(100)$ & $31 / 40(81.5)$ \\
\hline $\begin{array}{l}\text { Yes, National and Internation- } \\
\text { al degree }\end{array}$ & 0 & $2 / 40(5.2)$ \\
\hline None & 0 & $5 / 40(13.1)$ \\
\hline \multicolumn{3}{|l|}{ f. Highest level of education } \\
\hline Less than 12 years of school & 0 & 0 \\
\hline High school & 0 & 0 \\
\hline Vocational degree & 0 & $1(2.5)$ \\
\hline Incomplete university degree & 0 & 0 \\
\hline Completed university degree & $1(12.5)$ & $15(37.5)$ \\
\hline Specialty & $3(37.5)$ & $12(30.0)$ \\
\hline Master & $3(37.5)$ & $11(27.5)$ \\
\hline Doctorate & 0 & 0 \\
\hline Post-doc & 0 & 0 \\
\hline Other & $1(12.5)$ & $1(2.5)$ \\
\hline \multicolumn{3}{|l|}{$\begin{array}{l}\text { g. Level of education in the } \\
\text { addictions field** }\end{array}$} \\
\hline Fellowship & $4(50.0)$ & $11(27.5)$ \\
\hline Master & $2(25.0)$ & $2(5.0)$ \\
\hline Certificates/workshops & $5(62.5)$ & $25(62.5)$ \\
\hline None & 0 & $8(20.0)$ \\
\hline \multicolumn{3}{|l|}{$\begin{array}{l}\text { h. Primary responsibilities at the } \\
\text { site }^{* \star}\end{array}$} \\
\hline Direct contact with patients & $5(62.5)$ & $32(80.0)$ \\
\hline Physician & $1(12.5)$ & $8(20.0)$ \\
\hline Teaching & $3(37.5)$ & $4(10.0)$ \\
\hline Administration & $3(37.5)$ & $2(5.0)$ \\
\hline Other & $1(12.5)$ & $3(7.5)$ \\
\hline \multicolumn{3}{|l|}{ i. Personal recovery } \\
\hline Yes & 0 & $1(2.5)$ \\
\hline No & $8(100)$ & $39(97.5)$ \\
\hline
\end{tabular}

*Denominators presented only where there is missing data.

** Not mutually exclusive.

$* * *$ Mean age based on $n=40$

al interventions most commonly identified as 'frequently' used were MET (85.1\%) and Cognitive Behavioral Therapy (CBT, 78.2\%); with lesser use of Brief Strategic Family Therapy (BSFT, 34.7\%), 12 Step facilitation (22.7\%) and couples therapy $(17.3 \%)$. Only the use of a referral system, BSFT and psychiatric services, were significantly different among respondents, across the participating sites. These differenc-
Table 2. Site characteristics

\begin{tabular}{|c|c|c|}
\hline & $\begin{array}{l}\text { Directors } \\
n=8(\%)\end{array}$ & $\begin{array}{l}\text { Clinicians } \\
n=40(\%)\end{array}$ \\
\hline \multicolumn{3}{|l|}{ a. Theoretical framework } \\
\hline Cognitive Behavioral Therapy & $3(37.5)$ & $15(37.5)$ \\
\hline Bio-psychosocial & $3(37.5)$ & $8(20.0)$ \\
\hline Psycho-dynamic & $1(12.5)$ & - \\
\hline Eclectic & $1(12.5)$ & $6(15.0)$ \\
\hline Medical model (disease focused) & - & $6(15.0)$ \\
\hline Other & - & $5(12.5)$ \\
\hline \multicolumn{3}{|l|}{$\begin{array}{l}\text { b. } \% \text { of the patients with dual } \\
\text { diagnosis }\end{array}$} \\
\hline$>50 \%$ & $4(50.0)$ & $21(52.5)$ \\
\hline$\leq 50 \%$ & $4(50.0)$ & $19(47.5)$ \\
\hline \multicolumn{3}{|l|}{ c. Participation in the MET trial* } \\
\hline Yes & $5(62.5)$ & $12 / 40(30.7)$ \\
\hline No & $3(37.5)$ & $27 / 40(69.2)$ \\
\hline \multicolumn{3}{|l|}{$\begin{array}{l}\text { d. Knowledge of the Mexican } \\
\text { Clinical Trials Network* }\end{array}$} \\
\hline Yes & $6(75.0)$ & $18 / 40(46.1)$ \\
\hline No & $2(25.0)$ & $21 / 40(53.8)$ \\
\hline
\end{tabular}

*Denominators presented only where there is missing data.

es were driven by the fact that some sites had responded "not at all" and others "most frequently" to the use of these three practices, polarizing responses. A comparison of the reported current clinical practices and use of EBPs between sites that participated in the MET trial and those that did not showed that sites differed significantly only on the use of a referral system $\left(X^{2}=5.185, p=0.022\right)$.

The table 4 shows participants' level of readiness or motivation for the use of certain EBPs. Most participants reported readiness scores of four or higher for specific EBPs on a six point scale, with 1 representing "I'm not familiar" and 6 representing "I have been using and now maintaining". Respondents reported being more ready to adopt CBT $(83.3 \%)$ and MET (79.1\%), compared to 12 step facilitation $(58.3 \%)$, couples therapy $(56.2 \%)$, BSFT $(66.6 \%)$, and motivational incentives $(60.4 \%)$. There were no statistical significant differences when comparing readiness level towards EBPs between directors and clinicians (36.1 vs. 38.3; $p=0.609$ ), or when comparing those that participated in the MET trial with those that did not (37.8vs. 35.4; $p=0.463$ ). Additionally, when comparing centers that participated in the MET trial with non-participants with regard to responses to the question "are you interested in using EBPs?" the Fisher exact test was not significant $(p=.192)$.

The table 5 presents participants' attitudes towards the use of EBPs. Overall, directors and clinicians do not perceive EBPs as overly complicated and difficult to put into practice $(\mathrm{M}=1.7 ; \mathrm{SD}=0.5)$; and do not feel peer pressure against the use of EBPs $(M=1.5 ; S D=0.9)$. Most respondents indicated that they do not mind trying EBPs as long as it does not affect their current practices $(\mathrm{M}=3.7, \mathrm{SD}=1.1)$, and that using 
Table 3. Current clinical practices per directors and clinicians

\begin{tabular}{|c|c|c|c|}
\hline & \multicolumn{3}{|c|}{ Directors \& Clinicians $(n=48)(\%)$} \\
\hline & Not frequently & Frequently & $\begin{array}{c}\text { Fisher exact } \\
\text { test }^{* *}\end{array}$ \\
\hline \multicolumn{4}{|c|}{ a. Tools used to assess patient problems* } \\
\hline Addiction severity index & $31 / 48(70.4)$ & $13 / 48(29.5)$ & 0.931 \\
\hline DSM-IV/V & $8 / 48(18.1)$ & $36 / 48(81.8)$ & 0.115 \\
\hline ICD-10 & $10 / 48(21.7)$ & $36 / 48(78.2)$ & 0.416 \\
\hline \multicolumn{4}{|c|}{ b. Evidence-based interventions* } \\
\hline MET & $7 / 48$ (14.8) & $40 / 48(85.1)$ & 0.547 \\
\hline CBT & $10 / 48(21.7)$ & $36 / 48(78.2)$ & 0.887 \\
\hline Motivational incentives & $26 / 48(56.5)$ & $20 / 48(43.4)$ & 0.806 \\
\hline Couples therapy & $38 / 48(82.6)$ & $8 / 48$ (17.3) & 0.100 \\
\hline BSFT & $30 / 48(65.2)$ & $16 / 48(34.7)$ & 0.004 \\
\hline 12 Step facilitation & $34 / 48(77.2)$ & $10 / 48(22.7)$ & 0.164 \\
\hline c. Medical services* & $16 / 48$ (34.0) & $31 / 48(65.9)$ & 0.152 \\
\hline d. Psychiatric services* & $16 / 48(34.0)$ & $31 / 48(65.9)$ & 0.001 \\
\hline e. Food services* & $42 / 48(95.4)$ & $2 / 48 \quad(4.5)$ & 1.000 \\
\hline f. Housing services* & $40 / 48(90.9)$ & $4 / 48 \quad(9.0)$ & 0.106 \\
\hline g. Vocational orientation* & $34 / 48(75.5)$ & $11 / 48(24.4)$ & 0.236 \\
\hline h. Referral system & $22(45.8)$ & $26(54.1)$ & 0.002 \\
\hline
\end{tabular}

* Denominators presented only where there is missing data.

* * Fisher Exact Test, comparisons across 7 sites.

a treatment manual helps a therapist to evaluate and improve his/her clinical skill $(\mathrm{M}=1.9$; $\mathrm{SD}=0.9)$. When evaluating attitudes towards EBPs as measured by the sum of the items, directors had more positive attitudes than clinicians as reflected by their mean scores (11.8 vs. 17.4; $p=.0104$ ). There was no statistical significant difference when comparing those that participated in the MET trial with those that did not (18.0 vs. $15.2 ; p=.096)$.

The table 6 shows directors' perceptions of the relative importance of ten potential barriers for the implementation

Table 4. Readiness to adopt Evidence-Based Practices*

\begin{tabular}{|c|c|c|}
\hline & \multicolumn{2}{|c|}{ Directors \& Clinicians $(n=48)(\%)$} \\
\hline & $<4$ & $\geq 4$ \\
\hline $\begin{array}{l}\text { a. Medication to control } \\
\text { craving }\end{array}$ & $13 / 48(27.0)$ & $33 / 48(68.7)$ \\
\hline $\begin{array}{l}\text { b. Medications to control for } \\
\text { relapse }\end{array}$ & $14 / 48(29.1)$ & $32 / 48(66.6)$ \\
\hline $\begin{array}{l}\text { c. Medications for the treat- } \\
\text { ment of other psychiatric } \\
\text { conditions }\end{array}$ & $14 / 48(29.1)$ & $32 / 48(66.6)$ \\
\hline $\begin{array}{l}\text { d. Motivational Enhancement } \\
\text { Therapy (MET) }\end{array}$ & $6 / 48(12.5)$ & $38 / 48(79.1)$ \\
\hline $\begin{array}{l}\text { e. Cognitive Behavioral } \\
\text { Therapy (CBT) }\end{array}$ & $5 / 48(10.4)$ & $40 / 48$ (83.3) \\
\hline $\begin{array}{l}\text { f. Incentives to generate } \\
\text { motivation }\end{array}$ & $17 / 48(35.4)$ & $29 / 48(60.4)$ \\
\hline g. Couples therapy & $20 / 48(41.6)$ & $27 / 48$ (56.2) \\
\hline h. 12 Step facilitation & $18 / 48(37.5)$ & $28 / 48(58.3)$ \\
\hline $\begin{array}{l}\text { i. Brief Strategic Family } \\
\text { Therapy (BSFT) }\end{array}$ & $14 / 48(29.1)$ & $32 / 48(66.6)$ \\
\hline
\end{tabular}

*Denominators presented only where there is missing data. of EBPs. Directors were asked to provide a rank score for each of the barriers from 1-10; where 1 represented the most significant barrier and 10 the least significant.

The table shows the number of participants (counts) who considered a given barrier as the most significant and those who considered it second or third most significant. Directors believe that not having enough clinical staff, being unable to afford well-trained staff and inadequate psychiatric and medical support are the biggest barriers to adopting EBPs. Staff resistance to change, inadequate resources for training and inadequate time for new project implementation were considered among the least important barriers to adoption.

When comparing centers that participated in the MET trial with non-participants with regard to responses to the question "are you interested in using EBPs?" the Fisher exact test was not significant $(p=.192)$.

\section{DISCUSSION AND CONCLUSION}

To our knowledge, there are no prior published studies that assess Mexican community addiction treatment providers on their experiences, beliefs and readiness to adopt a range of evidence-based practices for substance abuse treatment. This study provides an assessment of substance abuse treatment providers of the newly created Mexican Clinical Trials Network. Interestingly, the majority of the workforce of the sites assessed were women, and most of the workforce in these sites had obtained some degree of higher education.

Results of this survey showed that the ASI was infrequently used as a diagnostic and evaluation tool. This is re- 
Table 5. Attitudes towards EBPs

\begin{tabular}{|c|c|c|c|c|}
\hline & \multicolumn{4}{|c|}{ Directors/Clinicians $(n=48)(\%)$} \\
\hline & $\begin{array}{l}\text { Disagree } \\
(\%)\end{array}$ & $\begin{array}{c}\text { Not sure } \\
(\%)\end{array}$ & $\begin{array}{l}\text { Agree } \\
(\%)\end{array}$ & $\begin{array}{c}\text { Mean } \\
\text { (Stand. Dev) }\end{array}$ \\
\hline $\begin{array}{l}\text { a. Evidence-based practices seem overly complicated and hard } \\
\text { to put into practice. }\end{array}$ & 82.9 & 14.8 & 2.1 & $\begin{aligned} M & =1.7 \\
(S D & =0.8)\end{aligned}$ \\
\hline $\begin{array}{l}\text { b. There are influential clinicians at my program that are defi- } \\
\text { nitely against evidence-based practices. }\end{array}$ & 76.6 & 14.8 & 8.5 & $\begin{aligned} M & =1.8 \\
(S D & =0.9)\end{aligned}$ \\
\hline $\begin{array}{l}\text { c. The idea of evidence-based practices sound good in "theory" } \\
\text { but in reality, it's virtually impossible to scientifically test a } \\
\text { phenomenon as complex as substance abuse treatment. }\end{array}$ & 73.9 & 21.7 & 4.3 & $\begin{array}{c}M=1.9 \\
(S D=0.8)\end{array}$ \\
\hline $\begin{array}{l}\text { d. The treatments that we do at our program may not be "evi- } \\
\text { dence-based", but they work just as well, or better. }\end{array}$ & 43.4 & 23.9 & 32.6 & $\begin{array}{l}M=2.7 \\
(S D=1.1)\end{array}$ \\
\hline $\begin{array}{l}\text { e. As long as they don't conflict with treatments already in place } \\
\text { at our program, I don't see any problem with using a few } \\
\text { procedures that are evidence-based. * }\end{array}$ & 15.2 & 10.8 & 73.9 & $\begin{array}{c}M=3.7 \\
(S D=1.1)\end{array}$ \\
\hline $\begin{array}{l}\text { f. Evidence-based practices make counselors more like techni- } \\
\text { cians than caring human beings. }\end{array}$ & 60.8 & 28.2 & 10.8 & $\begin{aligned} M & =2.3 \\
(S D & =1.0)\end{aligned}$ \\
\hline $\begin{array}{l}\text { g. Treatment manuals are appropriate for research clients but } \\
\text { not "real world" clients. }\end{array}$ & 61.7 & 19.1 & 19.1 & $\begin{aligned} M & =2.3 \\
(S D & =1.1)\end{aligned}$ \\
\hline $\begin{array}{l}\text { h. Using a treatment manual helps a therapist to evaluate and } \\
\text { improve his or her clinical skills. * }\end{array}$ & 8.5 & 8.5 & 82.9 & $\begin{aligned} M & =1.9 \\
(S D & =0.9)\end{aligned}$ \\
\hline $\begin{array}{l}\text { i. If a treatment has been shown scientifically to be effective, } \\
\text { then the counselor is ethically obligated to use the treatment as } \\
\text { opposed to one that has not been studied. }\end{array}$ & 17.0 & 17.0 & 65.9 & $\begin{array}{c}M=3.6 \\
(S D=1.1)\end{array}$ \\
\hline $\begin{array}{l}\text { i. Using evidence-based practices detracts from the authenticity } \\
\text { of the therapist interaction. }\end{array}$ & 65.9 & 25.5 & 8.5 & $\begin{array}{l}M=2.1 \\
(S D=0.9)\end{array}$ \\
\hline
\end{tabular}

markable as $54.1 \%(n=26)$ staff from sites that participated in this survey had received thorough training in the use of the ASI at the time when the network was established. While the association between level of training and adoption has been well established; ${ }^{19}$ this fact continues to demonstrate there are other factors involved in the process of adoption, implementation and sustainability ${ }^{20-23}$ and point towards training being critical but not sufficient. In terms of EBPs for

Table 6. Directors' perceptions on barriers for the implementation of EBPs

\begin{tabular}{lcc}
\hline & $\begin{array}{c}\text { Most } \\
\text { significant }\end{array}$ & $\begin{array}{c}\text { 2nd and 3rd } \\
\text { most significant }\end{array}$ \\
\hline $\begin{array}{l}\text { a. There is not enough clinical staff } \\
\text { b. Unable to afford well-trained } \\
\quad \text { staff }\end{array}$ & 3 & 3 \\
$\begin{array}{l}\text { c. Inadequate psychiatric support } \\
\text { d. Inadequate medical support }\end{array}$ & 2 & 1 \\
e. Client inappropriateness and/ & 2 & 0 \\
$\quad \begin{array}{l}\text { or resistance to change } \\
\text { f. Inadequate administrative/ }\end{array}$ & 1 & 0 \\
$\quad \begin{array}{l}\text { supervisory support } \\
\text { g. Staff resistance to change }\end{array}$ & 1 & 1 \\
h. Inadequate physical space & 1 & 0 \\
$\begin{array}{l}\text { (size, quality) } \\
\text { i. Too many existing demands, } \\
\quad \text { not enough time for new project } \\
\text { implementation }\end{array}$ & 0 & 0 \\
i. Inadequate resources for training & 0 & 2 \\
\hline
\end{tabular}

substance abuse treatment, providers reported frequent use of MET and CBT, and that they are either ready to implement and/or sustain these interventions. Providers were not ready to adopt 12 step facilitation and motivational incentives. This difference could be explained by the fact that, in Mexico, there has been more training and exposure on CBT and MET, than to 12 step facilitation and to motivational incentives. The adaptation and testing of the 12 step facilitation model within treatment programs of this researchprovider network could be a first step toward 12 step facilitation adoption. Moreover, if this model were found to be effective, its adoption and implementation would facilitate the engagement of substance abuse treatment seekers' in 12 step self help groups, which are currently widespread in Mexico.

Results on attitudes towards EBPs show that while most respondents were open to EBPs, which is critical for adoption, ${ }^{24}$ about one third of them agreed that the treatments that they used were not EBPs but they worked. Resistance to EBPs is found more at the staff level than at the director level, pointing towards the importance of considering all factors at the organizational level that influence adoption and sustainability ${ }^{25}$ and the importance of an organizational culture which supports the adoption of EBPs. ${ }^{26}$ Interesting$1 y$, directors expressed that not having enough staff, not being able to afford well trained staff and competing demands were the main barriers for the implementation of EBPs, but did not note resistance of the staff to change or lack of re- 
sources for training as barriers. Finally, no statistically significant differences were found in readiness to adopt and resistance to EBPs between sites that participated in the first clinical trial of MET supported by this network and those that did not.

\section{Limitations}

This study only included sites that participated in site selection of the first trial implemented in the Mexican Clinical Trials Network, therefore a limitation is the relatively small number of participating sites and respondents. The comparison between sites that participated in the first trial and the ones that did not is limited by the fact that a baseline assessment of site personnel was not conducted prior to their involvement in the network and their participation in the first trial, and therefore a causal inference regarding the impact of network and trial participation could not be examined. Also, while site selection for the first trial was done based on site staffing and patient flow, it is possible that selected sites were in fact different in their readiness to adopt EBPs. However, results did not reflect differences between sites. The use of self reported measures to capture practice, attitudes and barriers could be potentially biased by social desirability. Also, while the term evidence based practice was clearly explained in the introduction to the survey, it is possible that practice and readiness to EBPs was overreported due to the lack of understanding on what constitutes an EBP. For example, having attended a seminar and applying some techniques of a given model does not necessarily mean implementing the manualized intervention as tested and proofed to work. The last two limitations can only be overcome by direct observation of the practices delivered.

The CBT and the MET emerged as the most frequently used evidence based practices in the sites that are part of the Mexican Clinical Trials Network. Results demonstrate porviders' positive attitudes towards EBPs which are critical for adoption. Insufficient staff and being unable to afford well trained staff were reported as the most important barriers for adoption of EBPs. Results from this study not only provide a baseline of the workforce, practices and readiness to adopt EBPs within the Mexican Clinical Trials Network, but also help shape strategies for the dissemination of EBPs for substance abuse treatment in Mexico.

\section{Future directions}

Future studies could include the additional 41 sites that recently engaged in research in the network allowing for a broader representation of the workforce. Future longitudinal studies could evaluate the impact that the network has on the adoption of the interventions tested within it, and how sites that are part of the network differ from those that are not in their adoption of and attitudes toward EBPs.

\section{Funding}

This work was funded by the United States Agency of International Development, Department of State grants S-INLEC11GR020 and S-INLEC11GR0015. The opinions, findings and conclusions stated herein are those of the authors and do not necessarily reflect those of the United States Department of State.

\section{Conflict of interests}

Authors Horigian and Alonso were involved in the technology transfer process for the establishment of the Mexican Trials Network but were not involved in the data collection nor data analyses for this study.

\section{Acknowledgments}

We would like to specially thank the site principal investigators of the first trial implemented in the Mexican Clinical Trials Network, Ricardo Sánchez Huesca, Ph.D.; Carlos Lima Rodriguez Rodríguez, M.D.; Ana De la Fuente Martín, M.D., and participating institutions: Centros de Integración Juvenil, CIJ; Centro "Nueva Vida" de Atención Primaria para las Adicciones, Puebla-Sur, and Centro de Trastornos Adictivos, Instituto Nacional de Psiquiatría Ramón de la Fuente Muñiz; Centro Nacional Para la Prevención de las Adicciones (CENADIC) and Comisión Nacional Contra las Adicciones (CONADIC).

\section{REFERENCES}

1. Haug NA, Shopshire M, Tajima B, Gruber V et al. Adoption of evidence-based practices among substance abuse treatment providers. J Drug Education 2008;38(2):181-192. PMID: 18724657.

2. Marinelli-Casey P, Domier C, Rawson, $R$. The gap between research and practice in substance abuse treatment. Psychiatric Services 2002;53(8):984-7. PMID: 12161673.

3. McGovern MP, Fox TS, Xie H, Drake RE. A survey of clinical practices and readiness to adopt evidence-based practices: Dissemination research in an addiction treatment system. J Substance Abuse Treatment 2004;26: 305-312. PMID: 15182895.

4. McLellan A. Technology transfer in the treatment of addiction. J Substance Abuse Treatment 2002;22:169-70. PMID: 12072161.

5. Knudsen HK, Roman PM. Innovation attributes and adoption decisions: perspectives from leaders of a national sample of addiction treatment organizations. J Substance Abuse Treatment 2015;49:1-7. doi: 10.1016/j.jsat.2014.08.003.

6. Amodeo M, Ellis MA, Samet JH. Introducing evidence-based practices into substance abuse treatment using organization development methods. American J Drug Alcohol Abuse 2006;32(4):555-560. doi:10.1080/00952990600920250.

7. McCarty D, Fuller BE, Arfken C, Miller M et al. Direct care workers in the national drug abuse treatment clinical trials network: Characteristics, opinions, and beliefs. Psychiatric Services (Washington, D.C.) 2007;58(2):181-190. doi:10.1176/appi.ps.58.2.181.

8. Squires D, Gumbley SJ, Storti SA. Training substance abuse treatment organizations to adopt evidence-based practices: the Addiction Technology Transfer Center of New England Science to Service Laboratory. J Substance Abuse Treatment 2008;34(3):293-301. PMID: 17600652.

9. Tai B, Straus MM, Liu D, Sparenborg $S$ et al. The first decade of the national drug abuse treatment clinical trials network: Bridging the gap between research and practice to improve drug abuse treatment. Journal of Substance Abuse Treatment. 2010,38(Suppl 1): S4-13. doi: 10.1016/j.jsat.2010.01.011. 
10. Addiction Technology Transfer Center (ATTC), Network Technology Transfer Workgroup. Research to practice in addiction treatment: Key terms and a field-driven model of technology transfer. J Substance Abuse Treatment 2011;41(2): 169-178. http://dx.doi.org/10.1016/j. jsat.2011.02.006.

11. Horigian VE, Marín-Navarrete RA, Verdeja RE, Alonso E et al. Technology transfer for the implementation of a clinical trials network on drug abuse and mental health treatment in Mexico. Pan-American Health Organization. (In press).

12. Benjet C, Borges G, Medina-Mora ME, Fleiz C et al. Prevalence and socio demographic correlates of drug use among adolescents: results from the Mexican adolescent mental health survey. Addiction 2007;102:1261-1268. PMID: 17624976.

13. Rojas E, Real T, García S, Medina-Mora ME. Revisión sistemática sobre tratamiento de adicciones en México. Salud Ment 2011;34:351-365.

14. Ducharme LJ, Knudsen HK, Roman PM, Johnson JA. Innovation adoption in substance abuse treatment: exposure, trialability, and the Clinical Trials Network. J Substance Abuse Treatment 2007;32(4): 3219. doi:10.1016/j.jsat.2006.05.021.

15. Roman PM, Abraham AJ, Rothrauff TC, Knudsen HK. A longitudinal study of organizational formation, innovation adoption, and dissemination activities within the National Drug Abuse Treatment Clinical Trials Network. J Substance Abuse Treatment 2010;38(Suppl 1):S44-S52. doi: 10.1016/j.jsat.2009.12.008.

16. Lehman WE, Simpson DD, Knight DK, Flynn PM. Integration of treatment innovation planning and implementation: strategic process models and organizational challenges. Psychology Addictive Behaviors 2011;25(2):252-61. doi: 10.1037/a0022682.

17. Lundgren L, Amodeo M, Chassler D, Krull I et al. Organizational readiness for change in community-based addiction treatment programs and adherence in implementing evidence-based practices: a national study. J Substance Abuse Treatment 2013;45(5):457-65. doi: 10.1016/j. jsat.2013.06.007.
18. Lundgren $L$, Chassler $D$, Amodeo $M$, $D^{\prime}$ Ippolito $M$ et al. Barriers to implementation of evidence-based addiction treatment: a national study. J Substance Abuse Treatment 2012;42(3):231-8. doi: 10.1016/j. jsat.2011.08.003.

19. Glasner-Edwards S, Rawson R. Evidence-based practices in Aaddiction treatment: Review and recommendations for public policy. Health Policy 2010;97(2-3):93-104. doi:10.1016/j.healthpol.2010.05.013.

20. Aarons GA, Hurlburt M, Horwitz SM. Advancing a conceptual model of evidence-based practice implementation in public service sectors. Administration Policy Mental Health 2011;38(1):4-23. doi:10.1007/ s10488-010-0327-7.

21. Simpson DD, Flynn PM. Moving innovations into treatment: A stagebased approach to program change. J Substance Abuse Treatment. 2007;33(2):111-120. doi:10.1016/j.jsat.2006.12.023.

22. Fixsen DL, Blase KA, Naoom SF, Wallace F. Core implementation components. Research on social work practice. 2009;19:531-40. doi: 10.1177/1049731509335549.

23. Moullin JC, Sabater-Hernández D, Fernandez-Llimos F, Benrimoj SI A systematic review of implementation frameworks of innovations in healthcare and resulting generic implementation framework. Health Research Policy Systems. 2015;13:16. doi:10.1186/s12961-015-0005-z.

24. Aarons GA. Mental health provider attitudes toward adoption of evidence-based practice: The Evidence-Based Practice Attitude Scale (EBPAS). Mental Health Services Research 2014;6(2):61-74.

25. Prochaska JO, DiClemente CC. Transtheoretical therapy: Toward a more integrative model of change. Psychotherapy Theory Research Practice 1982;19(3):276-288.

26. Aarons GA, Sawitzky AC. Organizational Culture and Climate and Mental Health Provider Attitudes Toward Evidence-Based Practice. Psychological Services 2006;3(1):61-72. doi:10.1037/1541-1559.3.1.61. 